\title{
Evolution of the landscape, historical planning and elements of Odessa
}

\author{
Nadiya Yeksareva, Vladimir Yeksarev \\ Odessa State Academe of Construction \& Arhitecture, Ukraine, fax +38 04827438 66, \\ e-mail: yeksarevy_arch@list.ru
}

The shape of a modern city is determined by its "town-planning heredity", even when it seems that the elements of old lay-out and building have lost their former value. The main task of a town-planner is to help the city not to lose its own peculiarity. A key to the decision of this task lies through understanding of the city origin, which is hidden in the process of its beginning and previous historical development.

The city of Odessa is located in a southwest of Ukraine on the coast of the Black Sea along the Odessa bay. The city extends along the bay totally by $30 \mathrm{~km}$. The maximal width of the city is $10 \mathrm{~km}$. The area of the city within present borders makes 13000 hectares. The city is a large cultural, scientific and industrial centre of Ukraine.

The city of Odessa owes its foundation to the circumstances of historical and geopolitical character, availability of a sea harbour, and the form of its realization is caused by objective (natural) and subjective (skill, special level of its authors' culture) factors.

The peculiarity of formation of Odessa is creation of a favourable inhabitancy for a human in an adverse, aggressive environment of a southern steppe zone. "It was an unattractive rocky district, abruptly braking off to the sea, without the slightest vegetation, surrounded by a sandy desert from the side of Peresyp and by a wild steppe from the side of Dalnik. And here Odessa was under construction of savage and clay" [1]. Because of absence of building wood the main building material was the limestone, located as a powerful layer under city. Its extraction on the whole territory without restrictions caused the catacombs (underground mines) to appear, and that had resulted further serious ecological problems.

Climate (radiation-temperature, damption, wind peculiarities), ground and vegetative cover (structure of the ground), relief of the area (difference of slopes height) and special geomorphological conditions (the landslips), hydrographic (presence of the sea, lakes, estuaries) and geological (susceptibility to the seismic phenomena) conditions are the basement of structure of Odessa. The changes of a relief, the basic elements of which in Odessa are: a plateau, landsliding terraces and coastal territory, occur because of landslips, landslides, wavewash and superficial drain. Landsliding characteristics of the Odessa coast limited the possibility of formation of the city sea facade for a long time. The most part of the coastal line represents a landsliding site with high geodynamic activity (Figs 1,2). "To overcome such difficult natural conditions - immense steppe deprived of any wood vegetation, 
terrible heat in the summer and the terrible blizzards in the winter, stony, sandy ground, absence of sources of fresh water,- not only huge energy and invincible persistence are needed, but also laborious work and thorough all-round knowledge of the business" (Fig. 3) [2].

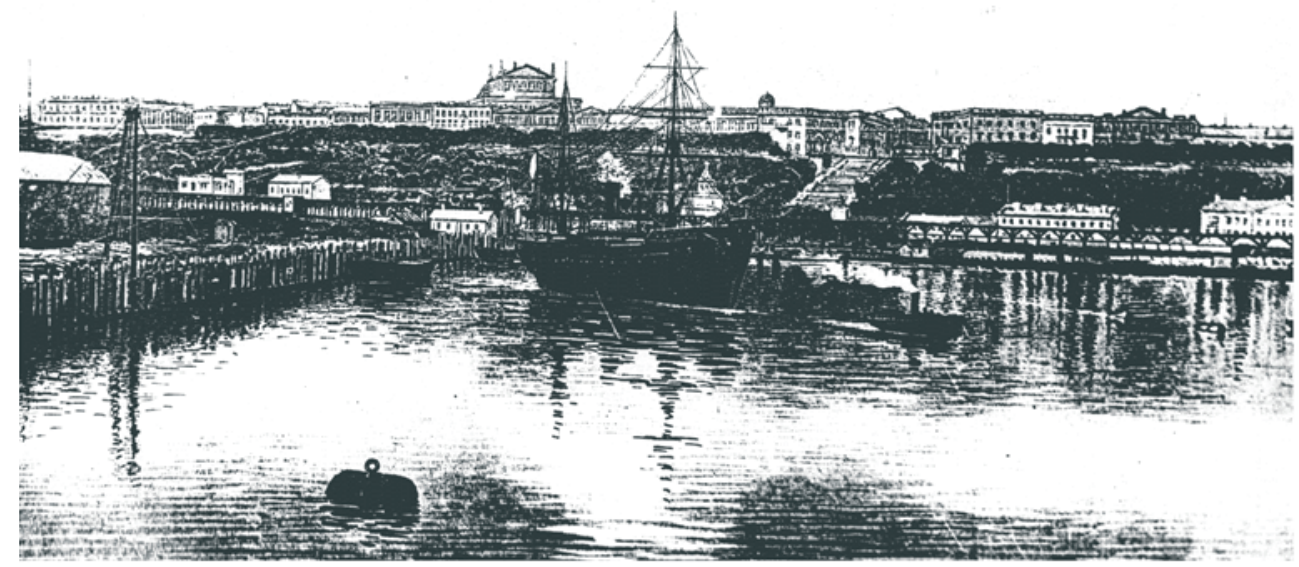

Морський фасад Одеси

Fig. 1. View from the sea.

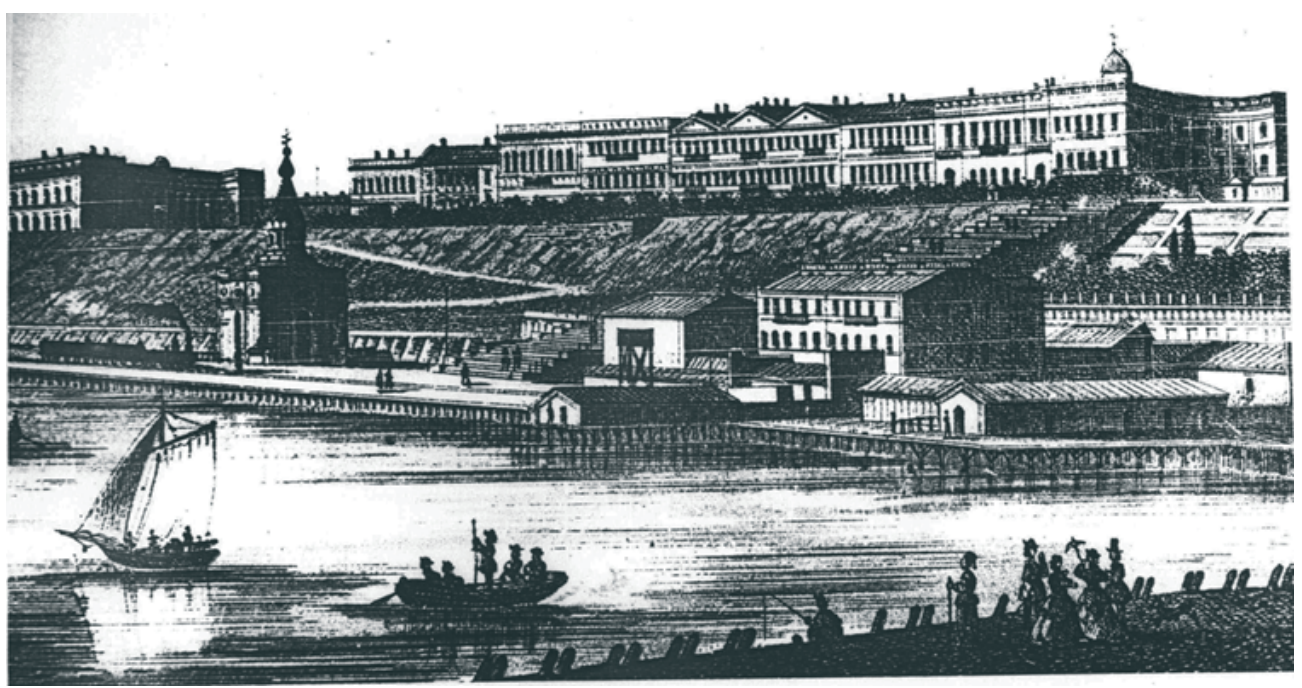

Fig. 2. View from the sea. 


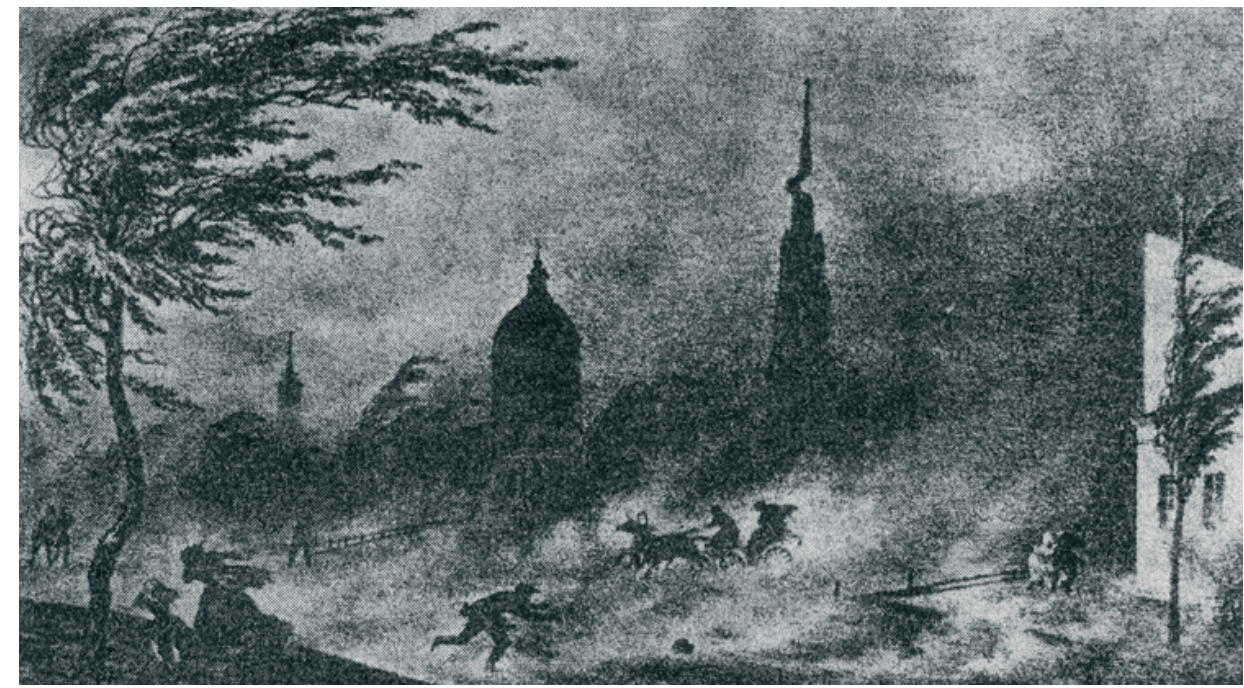

Fig. 3. Difficult natural conditions.

"The Plan of Khadjibey city", developed in January-February, 1794 by Fransois Devolan, is considered to be the high achievement of domestic town-planning culture of the Classicism period. In this plan the topography of the area is successfully used, the climate conditions and the military-defending structure of the city are taken into account, and the expressive planning decision is shown. The port was placed on a low coastal part. The inhabited zone is decided on an upper plateau with the large territorial reserve. Relating to the composition, the inhabited zone is represented by two grids of blocks located under a $45^{*}$ angle to each other. The trace of cardinis and decumanus streets of an antique lay-out is coordinated to Military and Quarantine ditches used as descents from the city to port (connection with the sea). The lay-out of the city is solved in complete conformity both with antique tradition and with the conditions of the area.

High professionalism of Fransois Devolan, his cultural keenness to the antique traditions of town-planning were shown even in the decision, taking into account the area and the season, of the most harmonious insolation of Odessa - city of the Sun, on the birthday of which the illumination becomes almost ideal (Fig. 4), [3].

The evolution of changes occurring in the interrelations of the developing planning structure with the sea coast, relief of the area and the measures taken for gardening and accomplishment of the city, creation of an anthropogenous landscape is given in the Table 1.

In the first stage (1794-1820) - the stage of birth of Odessa - a genetic code of destiny of the city was put, as well as the basis of its economic and cultural prosperity. One of the essential tasks becomes creation of an artificial landscape. The creation of private gardens, wineyards is characteristic for this period.

From the end of the XIX century there was a park on the Khadjibey leman, which occupied 10 hectares, and subsequently was a summer residence of the director of the Botanical garden Desmet, then Volochov, Shnel. In 1866 the park is taken by the city almost for free (only for 12000 roubles) for accommodation of a leman medical institution there [2]. 


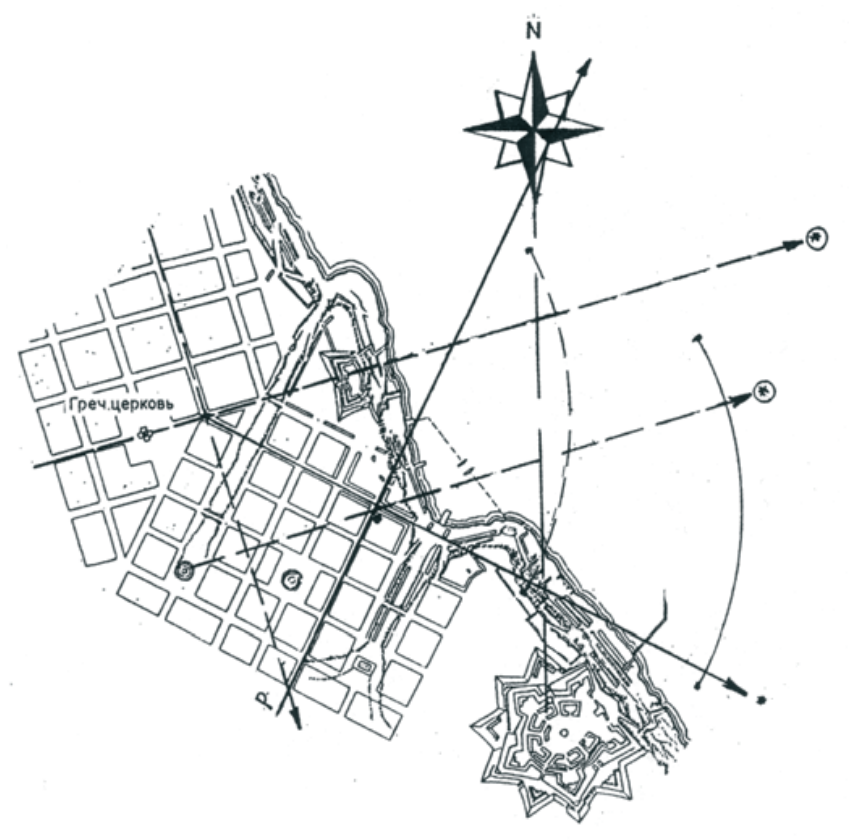

"План города Гаджибея"

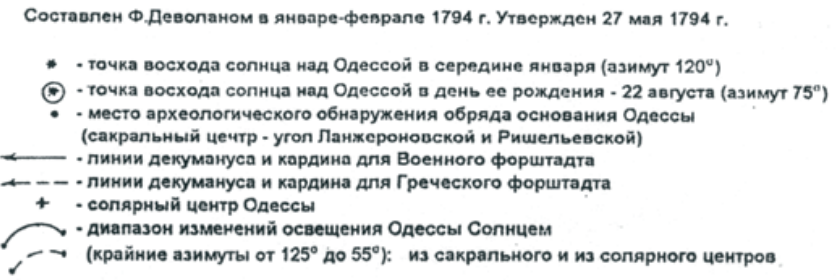

Fig. 4. Odessa - city of the Sun.

The first correct planting of the trees was provided by Felix De Ribas. He had carried out the dream of his brother - founder of Odessa - Admiral Joseph De Ribas, who favoured a summer residence 5 kilometers away from Odessa. The first trees in Odessa were planted by the brothers on an empty site of the city, in so-called Greek quarter. Count Felix Pototsky sent species for this garden from his famous Sofia park. The large garden (more than 2 hectares) in 1806 was gifted to the city and bears the name of City Garden.

During the first years of its existence Odessa was occupied by compact colonies of different ethnic and national groups, in the streets of the city such languages as Italian, Greek, Ukrainian, Russian, German, Bulgarian, Polish, Armenian and other were spoken. Ethnic variability among the population and mutual penetration of different cultures later resulted in a specific urban culture and peculiar mentality of the residents.

A valuable contribution was made by the following Italian architects who built Odessa: Francisco Frapolli, Giovanni Frapolli, Giovanni Torichelli, Georgiy Dallacva, Franc Boffo, Vaetano Dallacva, Giovanni Scudieri, Luigi Cambiaggia, Francesco Morandi, Giuseppe and Alexander Bernardazzi. (Figs 6, 7) 


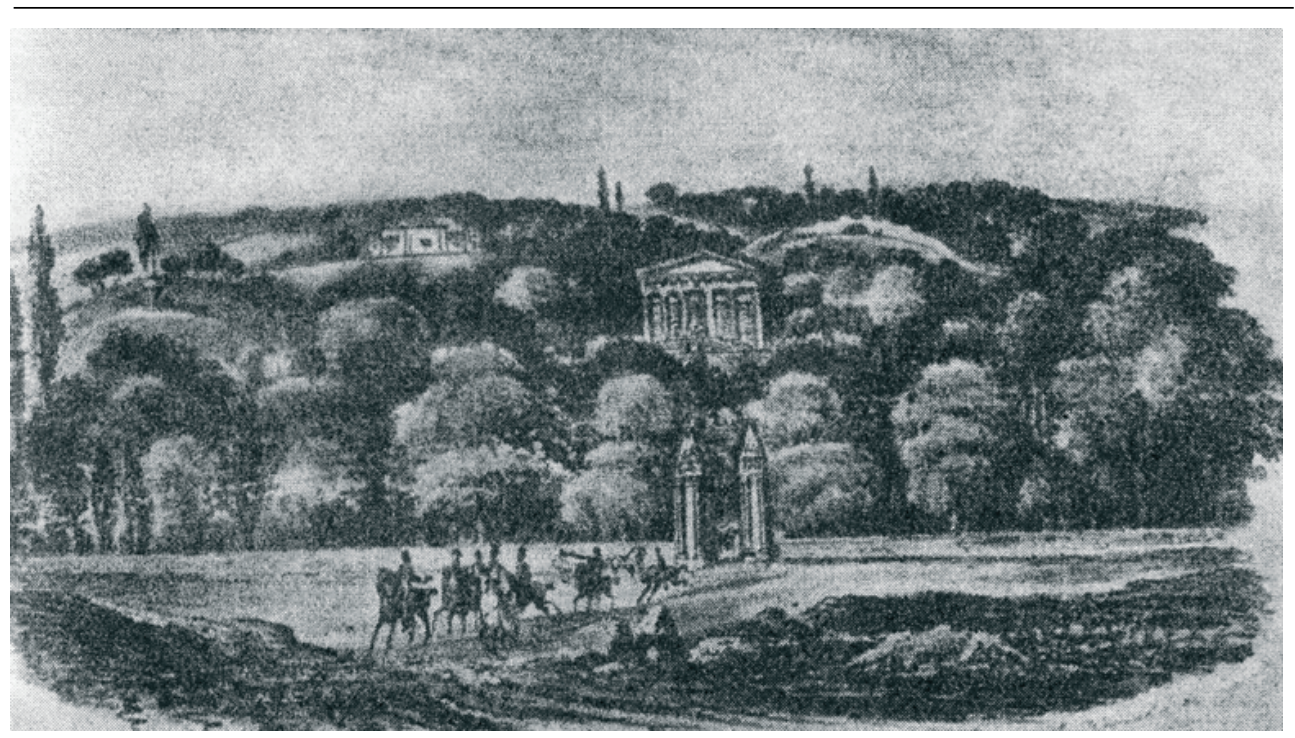

Fig. 5. Dukovskiy garden. Dacha of Rishell'e.

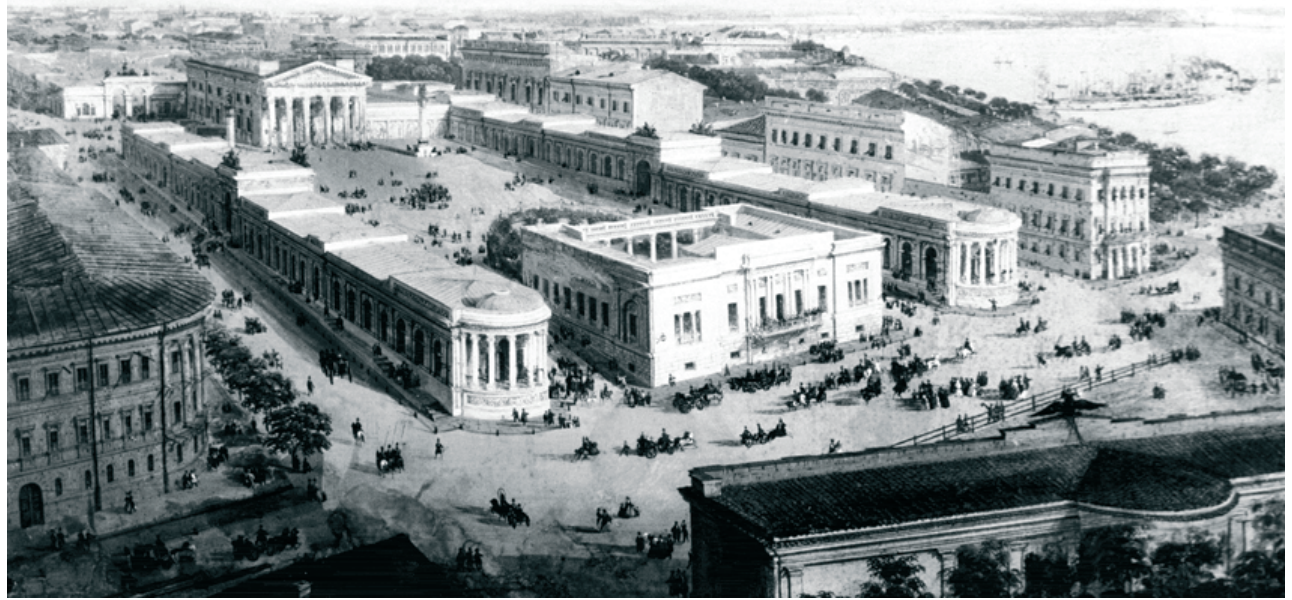

Fig. 6. Project of the Theatrical square G. Torichelli. 


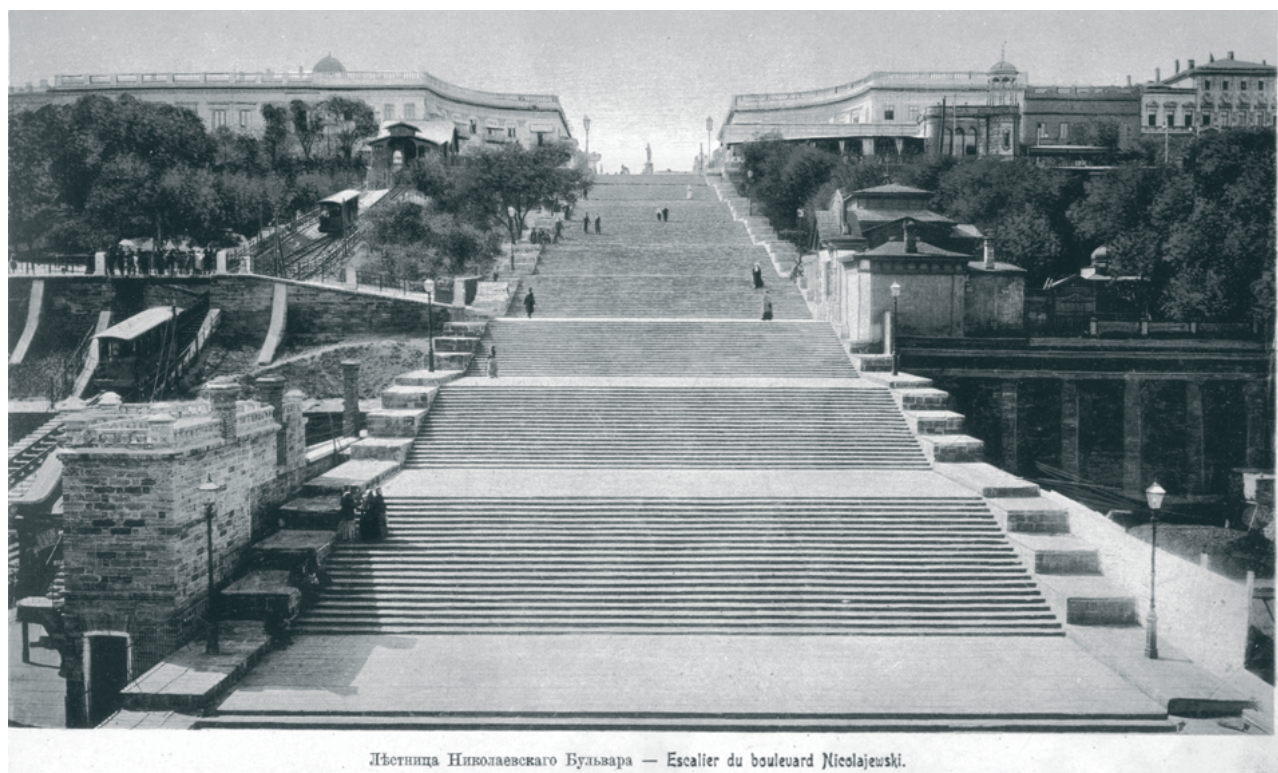

Fig. 7. Seaside steps.

It is interesting that all De Ribas brothers, though being on Russian service, remained the citizens of Napolitan kingdom. Felix De Ribas was married to a Polish woman Octavia Kachkovska, and after her death, to her cousine - Bronislava Malinovska [1].

The oldest wineyard in Moldovanka is considered to be the Greekman Sporiti's one, planted in 1798, and later belonging to madam Wobst. Since 1803 under the management of the head of the city Duke Emmanuil-de Rishileu the significant efforts were applied to, speaking by the words of Alexander Pushkin, force "the young branches to give the long-waited shadow during the hot day". The summer residence of Rishileu- Dukovsky Garden (15.5 hectares) was placed behind Moldovanka district, in a so-called Water ditch separating plateau on which the city from the next height is located (Fig. 5). The exclusive qualities of this place - security from cold and dry winds and presence of some brooks with fresh water - attracted Duke's attention. After some years the slopes of the ditch were covered by groves of acacias, birch, acetic tree, bushes of liliac, the species of which were brought by Rishilieu from Italy. On the places of brooks and rainwater sources the ponds and fountains were arranged. Neighbouring with the Dukovsky garden, on the same slope of the Water ditch, extensive summer residences of Benetato, Mandraji, Bortnikov, Count Razumovski, and gardens of beer-producing factories belonging to Rodokanka, Kempe, Durian, were located [2].

In the square limited by the Water ditch, streets Kolonicheskaya, Grape and Grape lane the farm of Carolina Sobanska, visited by Pushkin and Mitskevich, was located. "This lady lives rather hospitably, they say, her summer residence is open for a lot of Poles and here there are various talks, and rather freedom-loving ... " [4].

By the end of 20ieth XIX century the period of the city "infancy" was finished. Wheat-expertising operations made Odessa a port number one in Europe. In 1819 the city was given the status of Porto-Franco, which existed up to 1859. 
Table 1. The periods of formation of an artificial landscape of Odessa since 1794 till a beginning XX of century.

\begin{tabular}{ll}
\hline The periods & Measures on creation of an anthropogenic landscape. \\
\hline The I period & Construction, gardening and accomplishment of private summer \\
1794-1820 years & $\begin{array}{l}\text { residences, } \\
\text { manors, }\end{array}$ \\
$\begin{array}{l}\text { Defends-military } \\
\text { meaning of city. }\end{array}$ & $\begin{array}{l}\text { Origin of culture of a gardening, planting grapes. Import landing } \\
\text { material. }\end{array}$
\end{tabular}
The II period Creation of a botanical garden, network of parkways - Seaside, External.
1821-1840 years Distribution of sites of urban ground for cultivation of fruit gardens, Trading meaning grapes on Moldavanka, Peresip.
of city. $\quad$ Formation of suburbs - Near and Distant Mills, Slobodka-Romanovka.
An accomplishment of Balkovskaya street.
Increase of culture of agriculture. Growth of assignments on gardening of city. Creation of nursery.
The III period Encouragement of private gardens, grapes.
1841-1860 years Grandiose experiment on Peresip.
Creation Sea Planting of trees along post roads, on descents to the sea. An
shape of city.
accomplishment of places of common usage - Dukovsky and City
gardens.
Streets suburbs had by a limestone (shell rock) and plates of the Maltese breed.

The IV period

1861-1870 years

Growth

population.
Reduction of volume of assignments by gardening and accomplishment of city.

Reduction and destruction of a plenty of urban gardens.

\footnotetext{
Creation of zones of common usage - Alexandrovsky park, gardening of slopes Langeron, creation of a beach.

The $\mathrm{V}$ period $\quad$ Organization of a society of the gardeners, system of training.

1871-beginning Organization of nursery for gardening parkways, squares and cemeteries XX of century of city.

Resort meaning of Growth of urban and suburban gardens and summer residences with the city. device of a water-pipe.

Development gardening(planting) - of sandy grounds Peresip.

Streets suburbs by granite splinters, cast asphalt and gudron roads.
}

The next period (1821-1840), when the city becomes the capital of the region, gets importance of a "window to Europe and Forward Asia", is characterized by shifts to the authorities' participation in accomplishment and gardening of the Southern Palmira. By the decree dated by February 26, 1820 it is ordered to create an Imperial Botanical garden behind the Kulikovo-field square, most extensive of all belonging to the city -110 hectares. For its foundation from France the scientist of fruit gardens Yakov Dessemet [5] was invited. Since 1823 from the "nursery" of a Botanical garden annually 15 thousands of young trees were released. Later the Botanical garden was opened for everyone to walk in. Many gardens have appeared inside quarters, the squares were arranged at monasteries, Liceum, churches. 
The further gardening proceeded by connection of city areas by a network of parkways. In 20 years the green semi-circle $1.6 \mathrm{~km}$ long connected Preobrazhenskaya and Khersonskaya streets, which to the beginning XX cent. were almost completely built up. In 1827 again squares of the Alexander prospectus, in 1823 - avenues of Seaside parkway were planted. On the other side of the Military ditch in 1828 under the project of the architect F.K.Boffo, under the direction of the gardener German one more parkway, which stretched up to Pototsky's garden, was created. But the most extensive parkway was arranged on a line of the former defence ditch. This so-called External parkway by a wide ring surrounded the central part of city, from the Kherson descent up to the former fortress. Around the fortress parkway named after it also was created.

To accelerate the development of vegetation in vicinities of Odessa those who wished were given free sites of the ground for cultivation of fruit gardens and wineyards there, and also wood trees were distributed. Since 1827 under the decision of the State Council one who wished could receive 5 hectares of a land with obligatory building of a stone house and planting 100 trees or 400 bushes of a grapes on each hectare. After the edition of general rules for distribution of ground in Novorossiysk region and Bessarabia, since $1842-1$ hectar was given to everyone who wished with an obligatory to spread during three years 100 fruit trees or 1200 bushes (within 100 years). In the beginning of 30ies on such sites already 326 private gardens and wineyards exist, totally occupying 1725 hectares, that 5 times exceeded all urban green plantings including the Botanical garden and Levshynsky's plantations (Peresyp area).

Many private gardens appeared between the city, Middle and Big Fountains in the next period of development of the city - 1841-1860. In this period significant sums were assigned for cultivation of vegetation. Considerable staff of the employees was kept for watching gardens and plantations, it included the city gardener with four assistants, director of a Botanical garden, special inspector of External parkway and scientific forest warden with the salary 4000 roubles per year. In struggle with a poor nature Northern Black Sea Coast region the soil was exposed to serious processing, wells were dug, for planting fertile soil was delivered.

In 30ies and 40ies of the XIX of century a number of attempts in the field of a gardening or, more correctly, wood-planting, was undertaken, one of them- artificial planting in Peresyp - is the most grandiose of all undertaken on the Odessa ground. Since 1831 on Peresyp sands up to 40 thousand trees were planted, and tens of kilos of seeds were sown. In spite of the fact that a significant part of trees was dying from lack of water, planting and the crops persistently proceeded and by 1845 have formed huge 250-hectar plantation named after the city mayor A.I.Levshyn [2].

Under the order of the Governor-General, Count M.Vorontzov, in 1839-40 planting of trees along the city post roads was begun: the Nikolaev path and Balta road, beginning from the Peresyp plantation.

Despite of complexities with water supply, many gardens have arisen inside urban quarters, near private residences, churches, monasteries and educational institutions. The multiroom houses of the central quarters occupied all front of a quarter line, forming internal quarter. A surface of a court yard was covered with firm grades of local limestone and plates of imported volcanic stone. Here underground tanks were dug out, and rain and thawed water was collected there from the roofs. 
The accomplishment of City and Dukovsky gardens, establishment of PaleRoyal square testifies to the special attention paid to green plantings of public usage (Fig. 8). The descents to the sea on the Big and Middle Fountains also were planted. Under gardens and wineyards in 1846 in Odessa were registered 10512 hectares [2].

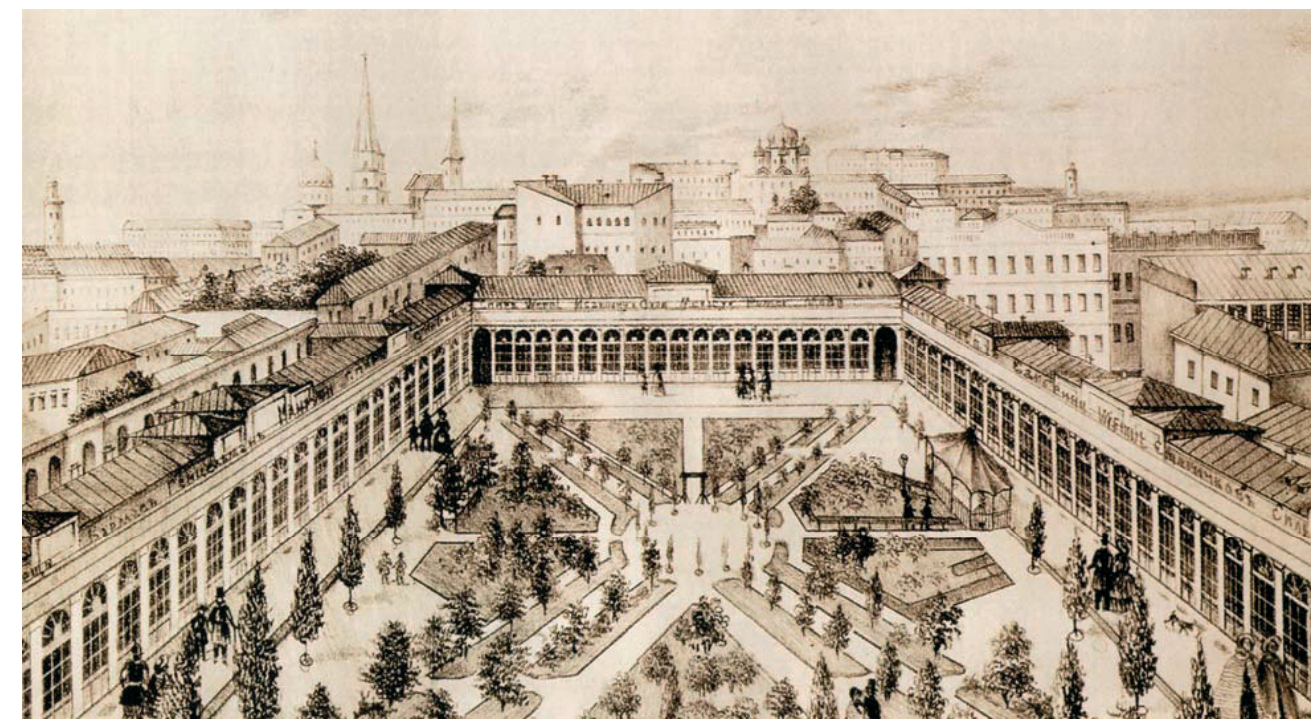

Fig. 8. Ensemble Pale Royal.

In this period the measures street pavement were undertaken. The sidewalks on separate sites were arranged from square plates of the Maltese lava. The descents from the city to port were paved by granite, highway of the majority of streets arranged from local limestone. But such a highway appeared to be uneconomical, quickly turning in dust and dirt, requiring constant repair.

The next stage of development of Odessa (1861 - beginning of the XX cent.) is characterized by intensive increase of the city territory, growth of an industrial zone. Owing to economic growth the population quickly grew, too. For instance, in 1866 120 thousand people lived here, in 1897 - 405 thousand, and in 1910 - 550 thousand. Development of port, construction of Petroleum and Grain harbours removed the city from the sea. The living buildings of the central area appeared to be blocked from the coastal line by industrial and warehouse territories.

With intencivity of housing construction at the centre, the erection of transport and industrial structures in suburbs destroyed plenty of gardens. This was promoted also by the fact that the budget of the city gardening, consisting in the twentieth of the XIXth century of 20000 roubles, was not increased within the whole decades [2].

In 1852 the former Botanical garden occupied 71.5 hectares of land. The third part of this space was sold by treasury, so by the end of the XIXth century only 47.5 hectares remained, of which 12 hectares was engaged in "nursery", and 4 were removed for an orphanage. By 1866, when the garden was handed to the city property, there already was complete desolation. Two groves - deciduous and coniferous have been enclosed with walls, and other space in good weather was filled with public for active rest (games, fun). 
On a place of Dragutinska plantation, located between External parkway and the Botanical garden, formed in 1840, by the end XIX of century were: Pavlovskoye building of cheap apartments, children's shelter and Junkers' school.

Some attempts to lift the city gardening were undertaken in 70ies, when Sobornaya square was planted by plants and fenced, the garden on the left side of Nikolaev parkway appeared, and the right half of the parkway was planted by two lines of perfect platans, covered by birches from the side of the sea. The creation of zones of public rest began. So, in 1875 according to the offer of a city head G.Marasli the beginning to park in Mihailovskaya square, named Alexander park (the first oak was planted by the emperor Alexander II in September 7, 1875). Here on the area of 22 hectares beautiful avenues, paths, bridges and flower beds were arranged. The park leaded to the New, or Alexander, parkway arranged in 1886 - a favourite place of Odessavites to walk. The formation of this large park was promoted by planting of plenty of trees and existence of Lanzheron beach on the neighbouring territory

The decisive and salutary influence on development of private and public undertakings on cultivation city and village gardens has rendered a structure of the Dnistrovsky waterpipe - water station on Dniester river, another one in the Plague mount and pipes in the territory of the city. It took the first place by the quality of drinking water and its extent $(40 \mathrm{~km})$ among Russian waterpipes, though already some serious difficulties because of increasing of the city and population growth were felt. The especially sharp lack was felt by the industrial enterprises and inhabitants of the sity suburbs.

On all seaside part to the south from the city, especially at the Small Fountain, at once after the waterpipe construction, with surprising speed began to develop private summer residences, plant wineyards and fruit gardens. That had perfectly changed the character of this formerly deserted district. Long-term works and expenses on an accomplishment of Malofontanskaya road (in 1902 renamed into the French parkway -Boulevard de France) have transformed this area into «a wonderful corner of the Beauty Odessa» (Fig. 9), [7].

Before the waterpipe construction, there were only several large and comfortable summer residences (Kortazzi, Marazli, Ralli, Rodokonaki etc.), for keeping and especially for watering of which huge money resources were spent. By Odessa 100 's anniversary one decorative and fruit gardens in vicinities occupied about 1000 hectares. Due to cultivation of medical species of a grapes Odessa received importance of a resort, not only for bathing, but also for grape treatment, $3 / 4$ of the young trees brought up in brothers Rothe, Stamm, Stapelberg, Dyber and Verkmeister nurseries, were directed behind the limits of the Odessa authorities.

In 1891 the parkway, and in 1892 - square around the city hospital on Kuyalnitsky liman was arranged. The extensive urban park on Khadjibey leman is put into order. The increase of number of gardens in Odessa caused necessity of making in 1892 one more nursery by the area of 10 hectares, located behind the New cemetery [2]. The small squares rose on Sobornaya, Railway, Alexeevska and other squares.

Beginning from 1878 under the direction of professor A.Verigo the project of a floatablebewerage system began, and since spring of $1888-20$ hectares of sandy lands in Peresyp started to irrigate with waste waters. By 1893 the area of fertiled kitchen gardens made 165 hectares, and bringing no income sands began to be rented up to 150 roubles per hectar and to bring two - three crops per season [2]. 


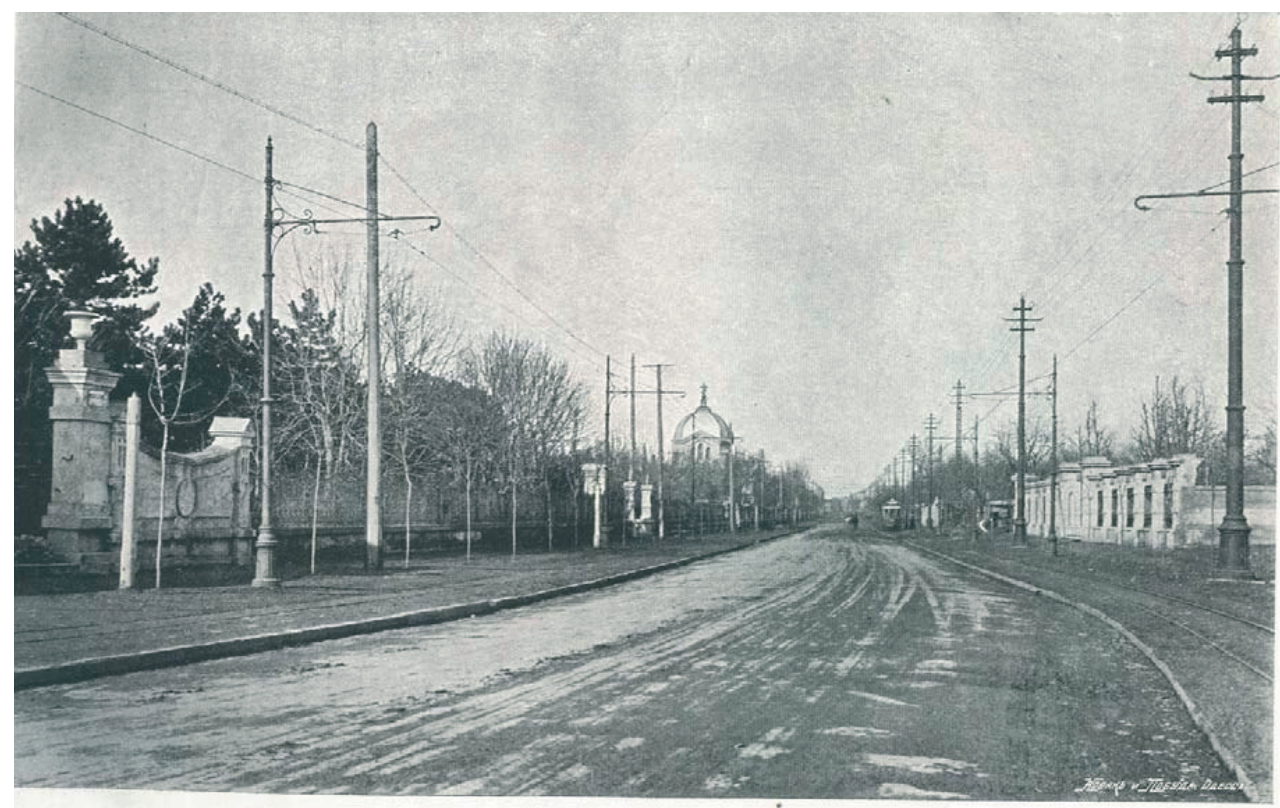

Французскій Бульваръ. Перспективный видъ отъ дачи А. К. Мартыновой къ городу.

Fig. 9. Malofontanskaya road - Boulevard de France.

The volumes of assignments on their contents testify to fast development of urban gardens, so if in 1884- 11600 roubles were allocated, in 1894 - already 28.359 roubles (100). In 1884 the Odessa department of an Imperial Russian society of gardening was open. It took active measures on improvement of this branch. In 1886 the initial school of gardening and kitchen-gardening for preparation of the experts was founded, because the urgent need in them was felt. Every summer at this school the free-of-charge monthly classes of gardening and kitchen gardening for folk teachers were open.

The urban public management was taking care of vegetation in urban cemeteries, to the beginning of the XXth cent. there were five of them: three christian (old and two new ones) and two Jewish.

The technical progress promoted increase of a level of urban accomplishment. By 1880 almost all streets of the central part and the basic highways in suburbs were paved by granite splinters. Granite pavement on the sandy basis of the suburbs appeared imperfect, the terms and quality of works sharply decreased. In 1874-1875 the cast asphalt road covering of the Primorsky boulevard was executed. Under the initiative of the city engineer V.I.Zuyev for the first time in the world practice tarring of a roadway of the French Boulevard was carried out in 1904 [7].

The beginning of the XX cent. was marked by the development of the new town-planning tendencies connected with the ideas of creation of a city - garden, - intensive development of suburbs: a settlement - garden "Self-help" in th 5-th station of the Big Fountain, French Boulevard, Novoarcadiyska road.

The retrospective review of stages of formation of an anthropogenous landscape of Odessa has allowed to reveal its historical-landscape skeleton, which should remain a basis of creation of ecologically healthy environment of a historical city. 


\section{Final notes}

Consideration of evolution of landscape and historical elements of Odessa will allow us to reveal the ways of appearing and the decision of questions concerning accomplishment and gardening of Southern Palmira.

Adverse climate and environmental conditions (the scorching sun, rocky seaside sites, steppe winds, sandy storms) caused the necessity of creation of a favourable artificial human inhabitancy.

In the rapidly growing city a place of rest behind the Kulikov field, the Khadjibey, Duke, Botanical, University, City, and other gardens were created. The Odessa garden was formed as a wood reserve from which the southern towns were supplied; trees were sent even to Saint Petersburg, Berlin and Warsaw.

The loss of certain sites of historical city environment causes irreplaceable breaks not only in the building itself, but also in that unique connection of old and new - one of the main secrets of the surprising viability of the city.

There is a necessity of integration of the reconstruction tasks, preservation of composite - structural qualities of a historical area - interrelations of ensembles and dominants, visual directions, panoramas and prospects, parities of architectural constructions, spaces and elements of a landscape.

The retrospective review of stages of formation of an anthropogenic landscape of Odessa has allowed to reveal historical landscape skeleton, which should remain a basis of creation of ecologically healthy environment of historical city.

\section{References}

[1] Deribas A.M., Staraya Odessa: Ist. Ocherki i vospominaniya, Odessa, 1913, 379 p.

[2] Odessa. 1794-1894, K stoletiyu goroda, Odessa: Obl.izd-vo, 1957, 318 p.

[3] Dobrolubskuy A., Odessa - gorod Solntsa: Restoration, reconstruction, urboecology, Materials sientific sumposium "RUR'98".- Odessa, ICOMOS, 1998, 293 p.

[4] Netrebskiy V., Progulki po staroiu Odesse, Odessa, 2002, 126 p.

[5] Smolianinov K., Istoriya Odessy, Odessa,1853, 284 p.

[6] Timoffeenko V.I., Odessa: Arkhitekturno-istoricheskiy ocherk, K. Budivelnyk, 1984, 160 p.

[7] Zuev V.I., Frantsuzskiy bulvar v Odesse, Odessa, 1915, 156 p. 